\title{
DNA distribution pattern and metabolite profile of wild edible lobster mushroom (Hypomyces lactifluorum/Russula brevipes)
}

\begin{tabular}{|c|c|}
\hline Journal: & Genome \\
\hline Manuscript ID & gen-2017-0168.R1 \\
\hline Manuscript Type: & Article \\
\hline Date Submitted by the Author: & 28-Dec-2017 \\
\hline Complete List of Authors: & $\begin{array}{l}\text { Laperriere, Genevieve; Universite du Quebec a Trois-Rivieres, Chimie, } \\
\text { biochimie et physique } \\
\text { Desgagné-Penix, Isabel; Universite du Quebec a Trois-Rivieres, Chimie, } \\
\text { biochimie et physique } \\
\text { Germain, Hugo; Universite du Quebec a Trois-Rivieres, Chimie, biochimie } \\
\text { et physique }\end{array}$ \\
\hline $\begin{array}{r}\text { Is the invited manuscript for } \\
\text { consideration in a Special } \\
\text { Issue? : }\end{array}$ & N/A \\
\hline Keyword: & $\begin{array}{l}\text { DNA, lobster mushroom, Hypomyces lactifluorum, Russula brevipes, } \\
\text { parasitism }\end{array}$ \\
\hline
\end{tabular}

SCHOLARONE

Manuscripts 
DNA distribution pattern and metabolite profile of wild edible lobster mushroom (Hypomyces lactifluorum/Russula brevipes)

\section{Genevieve Laperriere $^{1,2}$, Isabel Desgagné-Penix ${ }^{1,2}$, and Hugo Germain ${ }^{1,2}$}

${ }^{1}$ Department of Chemistry, Biochemistry and Physics, Université du Québec à TroisRivières, 3351 boul. des Forges, Trois-Rivières, QC, G9A 5H7, Canada

${ }^{2}$ Groupe de recherche en biologie végétale, Université du Québec à Trois-Rivières, 3351

boul. des Forges, Trois-Rivières, Québec, Canada G9A 5H7

GL : laperriere.genevieve@gmail.com

IDP : Isabel.Desgagne-Penix@uqtr.ca

Corresponding author: Hugo Germain (e-mail: hugo.germain@uqtr.ca) 


\begin{abstract}
Lobster mushroom is a wild edible mushroom with potential commercial value. It is the product resulting of the infection, most commonly of Russula brevipes by Hypomyces lactifluorum. This study undertook quantitative polymerase chain reaction analysis of tissues sampled at different infection stages, to investigate $R$. brevipes/H. lactifluorum interaction. We followed the colonization of $R$. brevipes sporocarps by $H$. lactifluorum which leads to the edible lobster mushrooms. In parallel, metabolomics analysis was performed to detect differences in metabolite profile among non-infected $R$. brevipes sporocarp and lobster mushroom. The results show that $H$. lactifluorum's DNA is not restricted to the margin, but is distributed relatively evenly across the sporocarp of the lobster mushroom. DNA of $R$. brevipes was also present throughout the sporocarp, but was less abundant at the margins and increased inwards. $R$. brevipes' DNA also declined as the infection progressed. Metabolomics analysis revealed that the flesh of lobster mushroom, which remains identical in appearance to the flesh of the host, undergoes transformation that alters its metabolite profile, most notably of lipids and terpene compounds. These results define a parasitic relationship between the two species which entails a decline of $R$. brevipes' DNA and a modification of its metabolite profile.
\end{abstract} Key words: DNA, lobster mushroom, Hypomyces lactifluorum, Russula brevipes, parasitism 


\section{Introduction}

Lobster mushroom is not a species, but the result from an infection of sporocarps of Russula spp. [most commonly Russula brevipes (Peck)] by Hypomyces lactifluorum (Schwein. Fr.) Tul. \& C. Tul., an ascomycete from the family Hypocreaceae in the order Hypocreales (Rogerson and Samuels 1994). This interaction is qualified as parasitism where Russula spp is the host and H. lactifluorum is the parasite (Beug et al. 2014; Hanlin 1963; Rogerson and Samuels 1994). Its distribution is confined to North America (Rogerson and Samuels 1994). This limited distribution could be explained by the similarly constrained spread of $R$. brevipes and ecological parameters, such as $\mathrm{pH}$, extractable soil phosphorus and stand opening, identified as important predictors of lobster mushroom's presence (Rochon et al. 2009).

There is sparse information on the infection process, life cycle and the colonisation of the host species during the infection such as how each of the two species is distributed throughout the sporocarp during the infection process. Hanlin (1963) suggested that $H$. lactifluorum infects very young Russula sporocarp, starting with infection of the gill surfaces, followed by rapid spread of the mycelia over the entire sporocarp. The growth of the host sporocarp continues, but gradually transforms as a result of the influence of the parasite. Rogerson and Samuels (1994) reported that $H$. lactifluorum appeared in consecutive years in the same populations of Lactarius or Russula species, indicating that infection may occur through H. lactifluorum-containing soil or that H. lactifluorum somehow grows in parallel with the host mycelium

There are other similar situations in the genus Hypomyces where the host sporocarp appearance is changed following Hypomyces colonization (Beug et al. 2014; 
McNeil 2006; Rogerson and Samuels 1994). Hypomyces chrysospermus (Tulasne) can colonize various boletes and covers the host sporocarp with a white layer followed by powdery yellow layer. Similarly, Amanita species sporocarp colonized by Hypomyces hyalinus (Schweinitz) Tulasne and C. Tulasne develop a fluffy crust with rough surface of various colors. Hypomyces luteovirens on Russula spp. and Hypomyces lateritus on Lactaria spp. are other similar cases. Among all these examples, none are considered edible or their edibility is unknown and gives to lobster mushroom a unique character.

The lobster mushroom resulting from the infection is edible and is characterized by an orange to reddish color of the cap surface while the underlying flesh remains white. Its main morphological characteristics are the presence of shallow ridges at the underside of the cap (remnants of the gills of Russula), as well as irregularity of the sporocarp and stalk (Hanlin 1963). R. brevipes, the most commonly reported host, has a bitter taste, but when associated with $H$. lactifluorum, to become lobster mushroom, is sought and appreciated by mushroom pickers for its meaty texture, distinctive flavor and good taste (McNeil 2006).

Since knowledge about this mushroom is limited, more information about its formation and structure is necessary to strengthen its utilization and commercialization. Our objectives were to better understand the composition of the lobster mushroom sporocarp during the colonisation of $R$. brevipes by H. lactifluorum. We also aimed to assess the metabolite composition profiles to try to understand the flavour changes between non-infected $R$. brevipes (white, bitter taste, non-edible) and lobster mushroom (orange, good taste, edible). To achieve the objectives, we used quantitative real-time polymerase chain reaction (qPCR) technology, to follow the presence of the two species 
inside the sporocarp of the lobster mushroom at different infection stages (partially colonized, completely colonized and decaying sporocarp). Finally, in order to evaluate if there were any metabolite changes between the $R$. brevipes and lobster mushroom (infected $R$. brevipes), we used HPLC and UPLC-qTOF-MS to assess the metabolite content.

\section{Materials and Methods}

\section{Mushroom collection and tissue sampling}

Non-infected $R$. brevipes sporocarps were collected in Parc regional des Grèves (Quebec, CAN) and in Gentilly (Quebec, CAN). Species were identified and confirmed by morphological features as well as Sanger sequencing of the entire ITS region (PCR conditions described hereafter). Infected sporocarps of three infected stages were collected at the Zec Bostonnais (Quebec, CAN) and near the Lake Sabourin (Quebec, CAN). The different infection stages included: i) partially infected sporocarps of $R$. brevipes still having visible gills and white outer flesh, but showing visible reddening of the cap, ii) completely infected sporocarps of $R$. brevipes also called lobster mushroom (sporocarp entirely red, with no visible gills, exhibiting a deformed cap and displayed characteristic orange color and firmer flesh than the Russula) and iii) decaying sporocarps of lobster mushrooms characterized by the same characteristics as the completely infected with softened red flesh, indicating that the mushroom has started to decay. Completely infected sporocarps of $R$. brevipes were cut into transversal cross-sections and pieces of an average of $0.04 \mathrm{~g}$ were collected, with a new scalpel blade, from the internal portion of the sporocarp. Care was taken not to contaminate each section with tissue/DNA from neighboring sections. Seven pieces from each sporocarp were collected 
and these pieces were numbered from the outermost part of the cap inward to the stalk $(0$ to 6). For the analyses of the proportion of $R$. brevipes and H. lactifluorum DNA in different infection stages of the lobster mushrooms sporocarp (non-infected R.brevipes, partially, completely and decaying lobster mushroom), tissues were collected at the cap's edge (equivalent of position 0 from Fig. 2), in the middle (equivalent of position 2 from Fig. 2) and in the stalk (equivalent of position 4 or 5 from Fig. 2).

\section{DNA extraction}

Fresh fungal tissue was placed in $200 \mu \mathrm{AP} 1$ buffer and pulverized by a hand drill mounted with a blue pestle, until a homogenous solution was obtained. Fungal DNA was extracted with DNeasy plant kit (Qiagen, Montreal, CAN), according to the manufacturer's instructions. DNA samples were kept frozen at $-20^{\circ} \mathrm{C}$ until analysis. $R$. brevipes DNA was obtained from sporocarps of non-infected $R$. brevipes. For $H$. lactifluorum, DNA was extracted from completely infected sporocarps of $R$. brevipes and isolated by cloning.

\section{PCR amplification and sequencing}

We amplified the whole ITS region for $R$. brevipes and $H$. lactifluroum for alignment and specific primers generation (to be used for qPCR analysis). Universal fungal primers ITS1-F (CTTGGTCATTTAGAGGAAGTAA) and ITS4 (TCCTCCGCTTATTGATATGC) (Gardes and Bruns 1993; White et al. 1990) we used. Sequences were compared with those available from the National Center for Biotechnology Information (NCBI) (http://www.ncbi.nlm.nih.gov/). PCR was performed with Phusion ${ }^{\circledR}$ High-Fidelity DNA Polymerase (New England Biolabs, Whitby, CAN), 
according to the manufacturer's instructions under the following conditions: 34 cycles of $10 \mathrm{~s}$ at $98^{\circ} \mathrm{C}, 30 \mathrm{~s}$ at $58^{\circ} \mathrm{C}$ and $30 \mathrm{~s}$ at $72^{\circ} \mathrm{C}$. Reactions were preceded by a 30 s denaturation step at $98^{\circ} \mathrm{C}$ and terminated with a 5 minutes elongation step at $72^{\circ} \mathrm{C}$. PCR products were separated by electrophoresis in $1 \%$ agarose gel with $1 \times$ TAE (Tris-Acetate-EDTA), stained with SYBR ${ }^{\circledR}$ Safe DNA Gel (Thermo Fisher Scientific, Ottawa, CAN) and visualized under UV light (ChemiDoc Touch Imaging System, Bio-Rad, Saint-Laurent, CAN). PCR products were purified by QIAquick PCR Purification Kit (Qiagen) and sent to the Québec Genome Innovation Centre of McGill University (Montreal, Quebec, CAN) for Sanger sequencing. Species identities were confirmed using the BLASTn algorithm from the NCBI nucleotide database and BOLDSYSTEMS (http://www.boldsystems.org).

\section{Cloning of H. lactifluorum ITS}

ITS PCR products were cloned with pBluescript II KS (+) vector. The vector was digested with the restriction enzyme EcoRV (New England Biolabs), and the amplified fragment was inserted by blunt-end ligation with T4 DNA ligase (New England Biolabs), according to the manufacturer's instructions. Ligation reactions were transformed in electro-competent Escherichia coli DH10B cells, and positive colonies containing recombinant plasmids were identified by blue/white selection on LB agar plates containing ampicillin $50 \mu \mathrm{g} / \mathrm{ml}$, X-gal $40 \mu \mathrm{g} / \mathrm{ml}$ and IPTG $0.2 \mathrm{mM}$. The plasmids were purified with QIAprep Spin Miniprep kit (Qiagen), and amplified fragment integration was confirmed by double digestion with the restriction enzymes EcoR1 and Xho1 (New England Biolabs). 


\section{Design and specificity testing of primers}

$H$. lactifluorum and $R$. brevipes sequences, obtained by sequencing the ITS region of genomic DNA, and sequences available on NCBI, were aligned with CLC MainWorkbench software 7.6.4 (Qiagen) to identify variable regions for primer design. For qPCR specific primers targeting smaller amplicons were designed for H. lactifluorum (H.L-1, ATTACCGAGTCTCCGAACTCCCAA and H.L-2, GATTCGTTTCGCTTGCCCTTTTCG) and for $R$. brevipes (R.B-1, CATCCTCAACCTGCTTCGTTCTATCG and

R.B-2, CGAGCGAAACCCAAGACGTAGAAAC-) with a combination of softwares, including Primer3 v. 4.0 .0 (http://primer3.ut.ee/) and CLC MainWorkbench v. 7.6.4 (Qiagen). The BLASTn algorithm available on NCBI was used to assess the in silico specificity of these primers. PCR amplification with novel specific primers was carried out with Hot Start Taq DNA Polymerase (New England Biolabs), according to the manufacturer's standard instructions under the following conditions: 34 cycles of $20 \mathrm{~s}$ at $95^{\circ} \mathrm{C}, 30 \mathrm{~s}$ at $56^{\circ} \mathrm{C}$ and $35 \mathrm{~s}$ at $68^{\circ} \mathrm{C}$. Reactions were preceded by a $30 \mathrm{~s}$ denaturation step at $95^{\circ} \mathrm{C}$ and terminated by a 5 minutes elongation step at $68^{\circ} \mathrm{C}$. PCR products were visualized as described previously.

\section{qPCR}

qPCR assays were performed in 96-well hard-shell PCR plates with the CFX Connect Real-Time system (Bio-Rad) according to the manufacturer's instructions. Each $20 \mu 1$ reaction mixture consisted of $10 \mu 1$ of $2 \mathrm{X}$ SsoAdvanced universal SYBR ${ }^{\circledR}$ Green Supermix (Bio-Rad), $0.5 \mu \mathrm{M}$ of each primer and $8 \mu$ of target DNA diluted 1/100. Each 
tissue sample underwent two technical replications with three biological replicates for each different infected stage. A negative control sample was included in each assay. The reference gene was the 5.8S ribosomal RNA encoding gene amplified with primers 5.8SF, CTTTCAACAACGGATCTCTTGGYTC and 5.8S-R, GCAAKGTGCGTTCAAAGATTCG, which were designed to amplify both species. Prior to the experiments, thermal gradient and dilution curves $(1,1 / 10,1 / 100,1 / 1,000$ and $1 / 10,000)$ were generated for each primer pair with pooled DNA samples to determine optimal annealing temperature and reaction efficiency. qPCR products from a few samples for each primer pair were visualized on agarose gel to confirm amplicon size and the absence of non-specific amplification and primer dimers. Amplicon purity was confirmed by melting curve analysis. The optimized thermal cycle protocol included 3 minutes incubation at $98^{\circ} \mathrm{C}$ followed by 39 cycles of $15 \mathrm{~s}$ at $98^{\circ} \mathrm{C}, 40 \mathrm{~s}$ at $60^{\circ} \mathrm{C}$ or $56.2^{\circ} \mathrm{C}$ for $H$. lactifluorum and $R$. brevipes respectively and 40 s at $72^{\circ} \mathrm{C}$ followed by melting curves from $65^{\circ} \mathrm{C}$ to $95^{\circ} \mathrm{C}$ with $0.5^{\circ} \mathrm{C}$ increments. Fluorescence threshold level was determined with the default adaptive baseline algorithm of CFX Manager Software 3.1.1517.0823. Relative quantitation assessed the relative amount of $H$. lactifluorum DNA versus $R$. brevipes' DNA at each position in the sporocarp. Normalized expression was calculated by the Livak method $\left(2^{-\Delta \Delta C T}\right)$ (Livak and Schmittgen 2001). In all cases, the lowest normalized expression served as calibrator, and error propagation was used to calculate standard deviation (Hellemans et al. 2007).

\section{Metabolites analysis}

Lobster mushrooms (completely infected) and non-infected $R$. brevipes sporocarp were used for HPLC-DAD (high performance liquid chromatography-diode array 
detector) analysis. Each mushroom sample (1 g) was ground in $10 \mathrm{ml}$ of $80 \%$ methanol and agitated for $24 \mathrm{~h}$ at room temperature. Extracts were filtered through Whatman paper No. 4. The filtered methanol/water solution was extracted twice with $10 \mathrm{ml}$ of $100 \%$ hexane. The aqueous phase was collected and evaporated at room temperature under a chemical hood. After evaporation, metabolites were re-suspended in $0.1 \mathrm{ml}$ of $20 \%$ methanol. The extracts were analysed with a Prominence-I liquid chromatograph HPLC (Shimadzu, Maryland, USA). Separation was achieved in an analytical reverse phase $\mathrm{C}_{18}$ column (Kinetex $5 \mu \mathrm{m} \times 150 \mathrm{~mm} \times 4.6 \mathrm{~mm}$, Phenomenex, California, USA) at $30^{\circ} \mathrm{C}$. The mobile phases were constituted of (A) $2.5 \%$ acetic acid in water and (B) $100 \%$ acetonitrile. $20 \mu \mathrm{l}$ of extract was injected and separated by the gradient method: $100 \% \mathrm{~A}$ for $5 \mathrm{~min}, 98 \% \mathrm{~A}$ and $2 \% \mathrm{~B}$ for $2 \mathrm{~min}, 80 \% \mathrm{~A}$ and $20 \% \mathrm{~B}$ for $2 \mathrm{~min}, 60 \% \mathrm{~A}$ and $40 \% \mathrm{~B}$ for $15 \mathrm{~min}, 40 \% \mathrm{~A}$ and $60 \% \mathrm{~B}$ for $10 \mathrm{~min}, 20 \% \mathrm{~A}$ and $80 \% \mathrm{~B}$ for $10 \mathrm{~min}, 2 \% \mathrm{~A}$ and $98 \%$ $\mathrm{B}$ for $6 \mathrm{~min}$ and, finally, $98 \% \mathrm{~A}$ and $2 \% \mathrm{~B}$ for $4 \mathrm{~min}$ at a flow rate of $0.5 \mathrm{ml} / \mathrm{min}$. DAD in full scan mode detected absorption at wavelengths between 190 to $800 \mathrm{~nm}$. To better understand the metabolites composition and their identity, one sample of completely infected and non-infected $R$. brevipes were analyzed using UPLC-MS (Ultra Performance Liquid Chromatography-Mass spectrometry). The UPLC-MS analysis was performed using a Waters Acquity Ultra-Performance LC system (Waters), equipped with a binary pump system (Waters). An Acquity Ethylene Bridged Hybrid (BEH) $\mathrm{C}_{18}$ column (100mm $\mathrm{x} 2.1 \mathrm{~mm}$ id $\mathrm{x}, 1.7 \mathrm{~mm}$ particle size) from Waters was used. The molecules were separated with a mobile phase that consisted of $0.2 \%$ acetic acid (eluent A) and acetonitrile (eluent B), the flow-rate was $0.2 \mathrm{~mL} / \mathrm{min}$. The initial elution gradient was $2 \% \mathrm{~B} ; 0-1 \mathrm{~min}, 2-100 \% \mathrm{~B} ; 1-30 \mathrm{~min}$, isocratic $100 \% \mathrm{~B} ; 30-33 \mathrm{~min}, 100-2 \% \mathrm{~B} ; 33-33.5$ 
min, isocratic 2\% B; 33-40 min. The MS analyses were carried out on a QTOF Micro mass spectrometer (Waters) equipped with a Z-spray electrospray interface. The analysis was performed in both positive and negative mode and the data were acquired through a masses scan form 100 to $1250 \mathrm{~m} / \mathrm{z}$ without collision. The ionization source parameters were; source temperature $120^{\circ} \mathrm{C}$; cone gas flow rate $50 \mathrm{~L} / \mathrm{h}$ and desolvation gas flow rate $350 \mathrm{~L} / \mathrm{h}$; desolvation temperature, $200^{\circ} \mathrm{C}$. Nitrogen $(99 \%$ purity) was used as nebulizing gas. Data acquisition was carried out with the MassLynx 4.1 software. Masses extraction, deconvolution, isotopes and library search was performed using MZMine 2 (Pluskal et al. 2010).

\section{Results}

\section{$\boldsymbol{H}$. lactifluorum and $\boldsymbol{R}$. brevipes primers produce specific amplicons}

Both primer pairs amplified genomic DNA extracted from a lobster mushroom (completely infected sporocarps of R. brevipes), which should contain both DNAs (Fig. 1, lane 2 and 6). PCR products generated with specific primers for H. lactifluorum (H.L-1 and H.L-2) and R. brevipes (R.B-1 and R.B-2) were detected at expected sizes, 207 bp for H. lactifluorum (Fig. 1, lane 1 and 2) and 164 bp for R. brevipes (Fig. 1, lane 6 and 7). No amplifications were detected with $H$. lactifluorum primers for $R$. brevipes genomic DNA (Fig. 1, lane 3) and with $R$. brevipes primers combined with plasmid containing the $H$. lactifluorum ITS fragment (Fig. 1, lane 5). We conclude that the primers designed yielded specific amplicons suitable for qPCR experimentation.

\section{Colonization of $\boldsymbol{R}$. brevipes by $\boldsymbol{H}$. lactifluorum in lobster mushroom sporocarp}

To assess the composition of the lobster mushroom sporocarp and to investigate the colonization of $R$. brevipes by $H$. lactifluorum, we conducted qPCR amplification. 
Melt curve was done for each reaction and in all cases only one dissociation curve was present. Samples were placed on a gel to visualize size and specificity of amplicons (Fig. S1). DNA from H. lactifluorum was detected throughout the sporocarp (Fig. 2b). Same results were obtained with other sporocarp (Figs. S2a and S2c). Interestingly, DNA from $R$. brevipes was less abundant at the cap's edge (position 0 and 6) than towards the interior of the sporocarp (position 3-5) (Fig. 2c). Its levels varied between the sporocarp tested, but it was always less abundant at the margin (Figs. S2b and S2d).

\section{Proportion of $\boldsymbol{H}$. lactifluorum and $\boldsymbol{R}$. brevipes in different infection stages of the lobster mushroom sporocarp}

A melt curve was performed and samples were placed on a gel as previously described. With $R$. brevipes primers no non-specific bands were detected (Fig. S3a). However, when using H. lactifluorum primers minor non-specific bands were detected in some of the stages, but $H$. lactifluorum specific band was always present (Fig. S3b), however these likely appeared very late in the PCR since they do not appear to affect quantitation; as seen in figure $2 \mathrm{~b}, \mathrm{H}$. lactifluorum is undetected in $R$. brevipes compared to infected mushroom. H. lactifluorum DNA was found to be increasingly present as the infection progressed (Fig. 3b). R. brevipes' DNA was also present in all stages, but was only detected at a very low level in decaying lobster mushroom sporocarp (Fig. 3c). Taken together, the data suggest that, as infection progresses, the $R$. brevipes' DNA declines in the sporocarp concurrently with the increasing H. lactifluorum DNA amount. Same results were obtained with other biological replicates with both primer pairs (Fig. S4). 


\section{Metabolites analysis of $\boldsymbol{R}$. brevipes and lobster mushroom sporocarps}

Although orange coloration of the lobster mushroom sporocarp (exterior) is much different from the white exterior of sporocarps of $R$. brevipes, the color and appearance of their interior flesh is identical. Various metabolites may be responsible for the differences in phenotype, taste and edibility of the two mushrooms. The HPLC results were identical respectively for all sporocarps and only one representative chromatogram is shown. A striking difference between chromatograms at $254 \mathrm{~nm}$ was seen between 32 and 38 min for extracts of $R$. brevipes (Fig. 4a) versus those of lobster mushroom (Fig. 4b). 3-D absorption plots, which allowed easier visualization of peaks throughout the light spectrum, showed similar striking differences including the presence of a peak between 30-35 minutes at 450nm in lobster mushroom (Figs. 4c and 4d). These results clearly demonstrate that $H$. lactifluorum alters the metabolite profile (composition and level) of R. brevipes flesh and contains metabolites absent from $R$. brevipes. UPLC-qTOF-MS detected a total of 183 masses in positive and negative mode, 38 of which were specific to the lobster mushroom and 78 were specific to $R$. brevipes (Table $\mathrm{S} 1$ ). In order to simplify the output of the mass spectrometry data, we grouped the metabolites into large families: lipids, alkaloids, terpenoids, phenolics, amino acids and others. The most striking difference between the general composition is the large diversity of terpenoids present in uninfected sporocarps of $R$. brevipes which are completely absent from the infected $R$. brevipes sporocarps (Fig. 5a and c). Conversely, the lobster mushroom contained a much larger diversity of lipid compounds (Fig. 5b) and amount of lipids (Fig. 5d) when compared with $R$. brevipes (Fig. 5c). Table S1 lists the detail of all the metabolites found in lobster mushroom and $R$. brevipes. 


\section{Discussion}

The complex biology of lobster mushroom is far from being fully understood and the $R$. brevipes and $H$. lactifluorum species distribution throughout the sporocarp and during the course of the infection process has not been examined previously. Results of our qPCR analysis show that H. lactifluorum's and $R$. brevipes' DNAs are both present in every infection stage analyzed and are distributed throughout the sporocarp. However, as the mushroom ages, the proportion of $R$. brevipes ' DNA relative to $H$. lactifluorum DNA decreases sharply, suggesting that $R$. brevipes is being degraded. We also show that the metabolite profile of $R$. brevipes is modified by the presence of $H$. lactifluorum.

In this study, we designed specific primer pairs and confirmed their specificity for amplifying $H$. lactifluorum and $R$. brevipes ITS regions (Fig. 1). Our results showed that H. lactifluorum's DNA is distributed throughout the sporocarp and is not limited to the margin, as hinted by the orange color present only at the sporocarp surface, in fact the parasite penetrates the sporocarp (Fig. 2b). As for $R$. brevipes, its DNA is also present throughout the whole sporocarp. It is, however, less abundant at the edge than in the middle of the cap (Fig. 2c). Hanlin (1963) observed infection of the gills on very young carpophore and he suggested that the H. lactifluorum mycelium, after infecting the gills, spreads to the entire cap surface. The surface of the $R$. brevipes sporocarp gets completely covered by a thick orange layer, as a result of skyrin production originating from the parasite (Helfer 1991; Poldmaa 2011). However, neither our results nor Hanlin can demonstrate whether the infection process is initiated from the outside of the sporopcarp or if the H. lactifluorum mycelium is also present inside when the red color appears at the surface. 
R. brevipes' DNA was present in all infected stages, but only at a very low level in completely infected sporocarp and decaying lobster mushroom (Fig. 3c). Moreover its presence in completely infected sporocarp reached its maximum level in the stipe although we see from figure 3 that the amount of $R$. brevipes DNA is very low at this stage, relative to that of H. lactifluorum DNA (Fig.3c). R. brevipes' DNA appeared to be degrading during the evolution of the infection and it was not the case for $H$. lactifluorum's DNA, which was still abundant (Fig. 3b). Our findings support parasitism between the two species, as proposed by other authors (Beug et al. 2014; Hanlin 1963; Rogerson and Samuels 1994). A parasitic system is an ecological relationship where the parasite benefits from its host either by feeding, hiding or breeding at its expense (Zelmer 1998). Parasitic fungi utilize nutrients from the host and have an entirely win-lose relationship (Petersen 2012). The decline of $R$. brevipes' DNA could be explained by the fact that traffic of the major nutriment is essentially one way from host to parasite (Lewis 1973). H. lactifluorum could steal available nutrients from $R$. brevipes and then expand through the sporocarp. Lacking proper nutrition, $R$. brevipes would deteriorate and die. We cannot rule out the possibility that $H$. lactifluorum could secrete a toxin or an enzyme to kill or digest $R$. brevipes to sustain its own growth.

\section{Difference in metabolite contents between $R$. brevipes and lobster mushroom}

We wanted to investigate a potential explanation for the gustative difference between $R$. brevipes, which does not have a good taste, and lobster mushroom, which presents a very distinct flavor really appreciated by consumers.

Major change between non-infected $R$. brevipes sporocarp and lobster mushrooms is the difference of diversity and amount of fatty acids compounds (Fig.5). Fatty acids 
were detected in much higher proportion in lobster mushrooms than non-infected $R$. brevipes (Fig. 5). Analyses of fatty acid composition revealed that several edible mushrooms showed a wide diversity of fatty acid (Pedneault et al. 2006; Ribeiro et al. 2009). Some of these species such as Russula cyanoxantha (Shaeffer) Fries, Suillus granulatus (Fries) Kuntze and Amanita caesarea Pomerleau are appreciated for their good taste (McNeil 2006). In most of the cases mushrooms shown a higher amount of unsaturated fatty acid versus saturated fatty acids (Dimitrijevic et al. 2017; León-Guzmán et al. 1997; Pedneault et al. 2006; Ribeiro et al. 2009). It was also the case of lobster mushroom (Table S1). However, unsaturated fatty acid could be precursors of flavor compounds and it was reported in tomato plant that a change in the level of fatty acid could change its flavor profile and consequently its taste (Wang et al. 1996).

Free amino acid was another compound more abundant in the lobster mushrooms than non-infected $R$. brevipes and some compounds as monosodium glutamate-like components (MSG-like) and 5' nucleotides were only detected in lobster mushroom (Fig. 5) (Table S1). Aspartic and glutamic acids were described as monosodium glutamate-like components (MSG-like) (Yamaguchi 1979). These components are found to be tasteactive and give flavor to mushrooms (Chen 1986). It also associated to the umami and palatable taste (Yamaguchi 1979). MSG-like are found in high proportion in some wild edible mushroom species as for example Amanita rubescens, Pleurotus ostreatus and Lentinula edodes (León-Guzmán et al. 1997; Yang et al. 2001). MSG-like and 5' nucleotides have a synergistic effect on flavour and increase the umami taste (Yamaguchi et al. 1971). Aspartic acid ( $\mathrm{M}+\mathrm{H}$ 146,0574) and pseudouridine ( $\mathrm{M}+\mathrm{H}$ 243,0846) detected in lobster mushrooms could play a role in it tasty flavor (Table S1). 
In addition, $R$. brevipes showed a higher abundance of terpene and phenolic compounds (Fig. 5a) while terpenes were not detected in the lobster mushroom (Fig. 5b). These secondary metabolites are more specific to plant, bacteria and fungi and are produced, in part, for protection and defense (Hopkins 2003). R. brevipes could produce a high diversity of these metabolites as a protectant against insects or fungivores. A group of sesquiterpenes were isolated in mushrooms of the Russulaceae family and some of these molecules had a pungent taste for human (Magnusson et al. 1973; Magnusson et al. 1972). A bioassay using a natural fungivore, the opossum Didelphis virginiana, identified five species of mushroom members of the Russulaceae family, previously reported as having a taste pungent to human, which were not eaten and rejected by the opossum (Camazine et al. 1983). These mushrooms may contain similar sesquiterpenoids as those identified in R. brevipes (Mizuno 1995). Indeed, several sequiterpenoid compounds were specifically detected in $R$. brevipes including lactarorufin $(\mathrm{M}+\mathrm{H}$ 265.1672) and turmerone $(\mathrm{M}+\mathrm{H}$ 265.1672) which may contribute to unliked aroma and taste (Table S1). Terpenoid compounds were not detected in the lobster mushroom (Fig. $5 \mathrm{~b}$ and d). Given that several terpenoid compounds are known to have a pungent and bitter taste, it is tempting to speculate that the absence to terpenoids in the lobster mushroom is a factor which makes it more palatable than R. brevipes (Figs. 5a and $\mathrm{b}$ ).

A striking difference between figures $5 \mathrm{a}$ and $5 \mathrm{~b}$ is the 'disappearance' of the terpenoid compounds, in particular sesquiterpene (Table S1) that seem to be converted into lipids when the $R$. brevipes is being infected. In fact, it is highly unlikely that sesquiterpenes or any terpenoids would be converted to fatty acids. To our knowledge no known enzyme can catalyze the direct conversion of sesquiterpenes or terpenoids into 
fatty acids. However, H. lactifluorum may have the capacity to catabolize terpenoids into simpler carbone-based molecules from which they could build lipids. A common element in the terpene and fatty acid biosynthesis pathway is acetyl coenzyme A (acetyl-CoA) (Hopkins 2003). When R. brevipes is uninfected acetyl-CoA would be used largely for the production of terpenes and more precisely sesquiterpenes (Table S1). When $H$. lactifluorum infects sporocarp of $R$. brevipes, the same enzyme could be used to the benefit of the fatty acid metabolic pathway.

\section{Conclusions}

To our knowledge, this is the first study using PCR technologies to analyse $H$. lactifluorum's and R. brevipes' relationship and that investigated the causes of the taste differences between the two mushrooms. The main findings described is that at the stage that lobster mushroom is eaten it contains only traces amount of $R$. brevipes in its sporocarp. However, our metabolite analyses demonstrated that the metabolite profile specific to $R$. brevipes has been completely altered and that several molecules of the terpenoid family, that may be responsible for the bad taste of $R$. brevipes, have disappeared and that fatty acids are very abundant in the lobster mushroom.

\section{Acknowledgements}

We thank the Berthoux Laboratory for providing pBlueScript vector, Melodie B. Plourde for technical support and critical manuscript review, and Aparna Singh for her expertise with HPLC. For funding we are thankful to the Natural Sciences and Engineering Research Council of Canada for a Discovery grant to H. Germain and the 
Université du Québec à Trois-Rivières for the research chair to H. Germain. Finally, we are indebted to Marcel Otis for providing pictures of $R$. brevipes and for his help as forest guide. 


\section{References}

Beug, M., Bessette, A.E., and Bessette, A.R. 2014. Ascomycete fungi of North America: a mushroom reference guide. University of Texas Press.

Camazine, S.M., Resch, J.F., Eisner, T., and Meinwald, J. 1983. Mushroom chemical defense. Journal of chemical ecology 9(10): 1439-1447.

Chen, H. 1986. Studies on the characteristics of taste-active components in mushroom concentrate and its powderization. Master's Thesis, National Chung-Hsing University, Taichung, Taiwan.

Dimitrijevic, M.V., Mitic, V.D., Jovanovic, O.P., Stankov Jovanovic, V.P., Nikolic, J.S., Petrovic, G.M., and Stojanovic, G.S. 2017. Comparative Study of Fatty Acids Profile in Eleven Wild Mushrooms of Boletacea and Russulaceae Families. Chemistry \& biodiversity.

Gardes, M., and Bruns, T.D. 1993. Its Primers with Enhanced Specificity for Basidiomycetes Application to the Identification of Mycorrhizae and Rusts. Mol Ecol 2(2): 113-118. doi: DOI 10.1111/j.1365-294X.1993.tb00005.x.

Hanlin, T.R. 1963. Morphology of Hypomyces lactifluorum. Botanical Gazette 124(6): 395-404.

Helfer, W. 1991. Pilze auf Pilzfruchtkörpern. Untersuchungen zur Ökologie, Systematik und Chemie. Libri Bot. 1: 1-157.

Hellemans, J., Mortier, G., De Paepe, A., Speleman, F., and Vandesompele, J. 2007. qBase relative quantification framework and software for management and automated analysis of real-time quantitative PCR data. Genome biology 8(2): R19. doi: 10.1186/gb-2007-8-2-r19.

Hopkins, W.G. 2003. Physiologie végétale. De Boeck Supérieur.

León-Guzmán, M.F., Silva, I., and López, M.G. 1997. Proximate chemical composition, free amino acid contents, and free fatty acid contents of some wild edible mushrooms from Querétaro, México. Journal of Agricultural and Food Chemistry 45(11): 4329-4332.

Lewis, D. 1973. Concepts in fungal nutrition and the origin of biotrophy. Biological Reviews 48(2): 261-277.

Livak, K.J., and Schmittgen, T.D. 2001. Analysis of relative gene expression data using real-time quantitative PCR and the 2(-Delta Delta C(T)) Method. Methods 25(4): 402-408. doi: 10.1006/meth.2001.1262.

Magnusson, G., Thorén, S., and Drakenberg, T. 1973. Fungal extractives-IV: Structure of a novel sesquiterpene dialdehyde from Lactarius by spectroscopic methods. Tetrahedron 29(11): 16211624.

Magnusson, G., Thorén, S., and Wickberg, B. 1972. Fungal extractives I. Structure of a sesquiterpene dialdehyde from Lactarius by computer simulation of the NMR spectrum. Tetrahedron Letters 13(12): 1105-1108.

McNeil, R. 2006. Le grand livre des champignons du Québec et de l'Est du Canada. Éditions M. Quintin.

Mizuno, T. 1995. Bioactive biomolecules of mushrooms: food function and medicinal effect of mushroom fungi. Food Reviews International 11(1): 5-21.

Pedneault, K., Angers, P., Gosselin, A., and Tweddell, R.J. 2006. Fatty acid composition of lipids from mushrooms belonging to the family Boletaceae. Mycological research 110(10): 1179-1183. Petersen, H.J. 2012. The kingdom of Fungi. Princeton University Press, Denmark.

Pluskal, T., Castillo, S., Villar-Briones, A., and Oresic, M. 2010. MZmine 2: modular framework for processing, visualizing, and analyzing mass spectrometry-based molecular profile data. BMC bioinformatics 11: 395. doi: 10.1186/1471-2105-11-395.

Poldmaa, K. 2011. Tropical species of Cladobotryum and Hypomyces producing red pigments. Studies in Mycology 68: 1-34. 
Ribeiro, B., de Pinho, P.G., Andrade, P.B., Baptista, P., and Valentão, P. 2009. Fatty acid composition of wild edible mushrooms species: A comparative study. Microchemical Journal 93(1): 29-35.

Rochon, C., Pare, D., Khasa, D.P., and Fortin, J.A. 2009. Ecology and management of the lobster mushroom in an eastern Canadian jack pine stand. Can J Forest Res 39(11): 2080-2091. doi: Doi 10.1139/X09-118.

Rogerson, C.T., and Samuels, G.J. 1994. Agaricicolous Species of Hypomyces. Mycologia 86(6): 839-866. doi: Doi 10.2307/3760597.

Wang, C., Chin, C.-K., Ho, C.-T., Hwang, C.-F., Polashock, J.J., and Martin, C.E. 1996. Changes of fatty acids and fatty acid-derived flavor compounds by expressing the yeast $\Delta-9$ desaturase gene in tomato. Journal of agricultural and food chemistry 44(10): 3399-3402.

White, T.J., Bruns, T., Lee, S., and Taylor, W.J. 1990. Amplification and direct sequencing of fungal ribosomal RNA genes for phylogenetics. Academic Press, Inc., New-York. pp. 315-322.

Yamaguchi, S. 1979. The umami taste. ACS Publications.

Yamaguchi, S., Yoshikawa, T., Ikeda, S., and Ninomiya, T. 1971. Measurement of the relative taste intensity of some I- $\alpha$-amino acids and 5'-nucleotides. Journal of Food Science 36(6): 846849.

Yang, J.-H., Lin, H.-C., and Mau, J.-L. 2001. Non-volatile taste components of several commercial mushrooms. Food chemistry 72(4): 465-471.

Zelmer, D.A. 1998. An evolutionary definition of parasitism. International journal for parasitology 28(3): 531-533. 


\section{Figure Legends}

Fig. 1 PCR amplification products obtained with specific primers for H. lactifluorum (H.L-1, H.L-2) and R. brevipes (R.B-1, R.B-2). Plasmid H.l corresponds to plasmid DNA containing $H$. lactifluorum ITS fragment, gDNA L.M corresponds to genomic DNA extracted from a lobster mushroom, gDNA R.b. corresponds to genomic DNA extracted from a non-infected $R$. brevipes sporocarp. Negative $=$ negative control.

Fig. 2 qPCR results of $H$. lactifluorum's and $R$. brevipes' DNA inside sporocarp of lobster mushroom. (A) Sporocarp transversal cross-section and localization of sampled tissues. Samples 0 to 6 indicate sampled tissue localization. (B) qPCR results of $H$. lactifluorum's and (C) of $R$. brevipes' DNA inside lobster mushroom.

Fig. 3 qPCR results of $H$. lactifluorum's and $R$. brevipes' DNA at different infection stages and in non-infected R. brevipes. (A) Pictures of different infected sporocarps: noninfected $R$. brevipes, partially infected, completely infected (mature lobster mushroom) and decaying lobster mushroom sporocarp. (B) qPCR results of H. lactifluorum's DNA and (C) of $R$. brevipes' DNA in a series of samples at different infection stages. Tissues were collected at the cap's edge (equivalent of position 0 from Fig. 2), in the middle (equivalent of position 2 from Fig. 2) and in the stalk (equivalent of position 4 or 5 from Fig. 2).

Fig. 4 HPLC chromatogram of extracts from non-infected $R$. brevipes and lobster mushroom sporocarps. (A) HPLC chromatogram at $254 \mathrm{~nm}$ of non- infected $R$. brevipes and (B) lobster mushroom extracts. (C) 3-D HPLC plot showing the 15-40 min range of $R$. brevipes and (D) lobster mushroom. 
Fig. 5 Pie chart indicating some compounds groups detected by UPLC-qTOF-MS analysis. Percentage of diversity of the selected families of compounds for (A) noninfected $R$. brevipes and (B) lobster mushroom and the relative amount of each compound group calculated with the total area under the curve for (C) non-infected $R$. brevipes and (D) lobster mushroom. 


\section{Supplementary Data}

gen-2017-0168.R1Suppla: Fig. S1 Amplicons place on agarose gel after qPCR reaction with both specific primers on mature lobster mushroom sporocarp for one biological replicate. (A) R. brevipes primers (R.B-1, R.B-2) and (B) H. lactifluorum primers (H.L-1, H.L-2). Numbers 0 to 6 indicate sampled tissue localization in the sporocarp (lobster mushroom). Negative $=$ negative control.

gen-2017-0168.R1Supplb: Fig. S2 qPCR results of H. lactifluorum's and $R$. brevipes' DNA inside sporocarp of lobster mushroom in two other biological replicates. (A) and (C) qPCR results for H. lactifluorum's DNA and (B) and (D) for R. brevipes's DNA. Samples 0 to 6 indicate sampled tissue localization.

gen-2017-0168.R1Supplc: Fig. S3 Amplicons placed on agarose gel after qPCR reaction with both primers pairs on different infection stages and in non-infected $R$. brevipes. (A) R. brevipes primers (R.B-1, R.B-2) and (B) H. lactifluorum primers (H.L-1, H.L-2). All infection stages are represented: non-infected sporocarp of $R$. brevipes, partially infected, completely infected and decaying lobster mushroom sporocarp. M (margin), C (center) and S (stalk) indicate sample tissue localization.

gen-2017-0168.R1 Suppld: Fig. S4 qPCR results of H. lactifluorum's and R. brevipes' DNA at different morphological infection stages and in non-infected $R$. brevipes in two other biological replicates. (A) and (C) qPCR results for H. lactifluorum's DNA and (B) and (D) for R. brevipes' DNA.

gen-2017-0168.R1Supple: Table S1. Raw metabolomics data's obtained in non-infected $R$. brevipes $\left(\mathrm{RU} \_\mathrm{NEG}=\right.$ Russula negative mode and $\mathrm{RU} \_\mathrm{POS}=$ Russula positive mode $)$ 
and lobster mushroom sporocarp (DRS_NEG= Lobster mushroom negative mode and DRS_POS= Lobster mushroom positive mode) by UPLC-qTOF-MS analyses. 


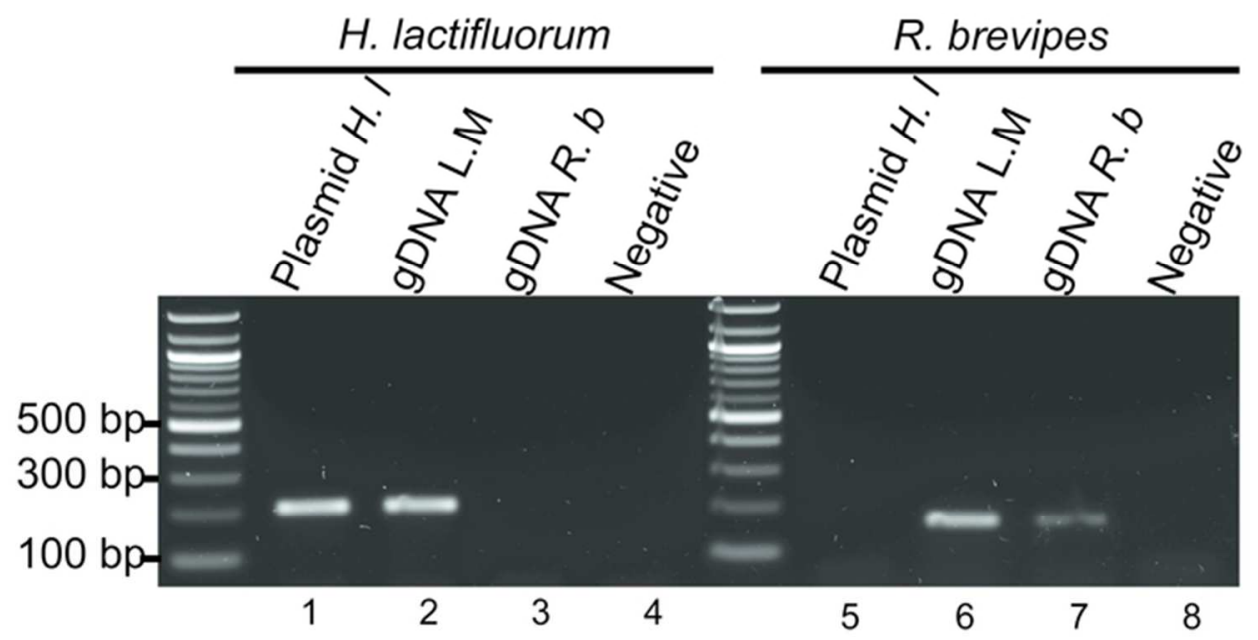

Fig. 1 PCR amplification products obtained with specific primers for H. lactifluorum (H.L-1, H.L-2) and R. brevipes (R.B-1, R.B-2). Plasmid H.I corresponds to plasmid DNA containing H. lactifluorum ITS fragment, gDNA L.M corresponds to genomic DNA extracted from a lobster mushroom, gDNA R.b. corresponds to genomic DNA extracted from a non-infected R. brevipes specimen. Negative = negative control.

$31 \times 15 \mathrm{~mm}(600 \times 600 \mathrm{DPI})$ 


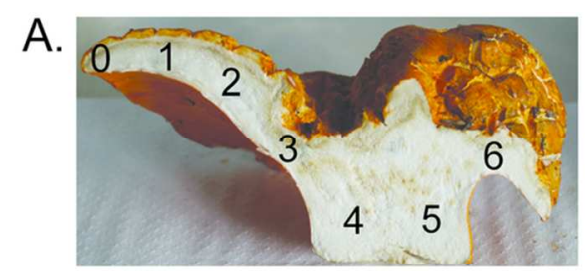

B.

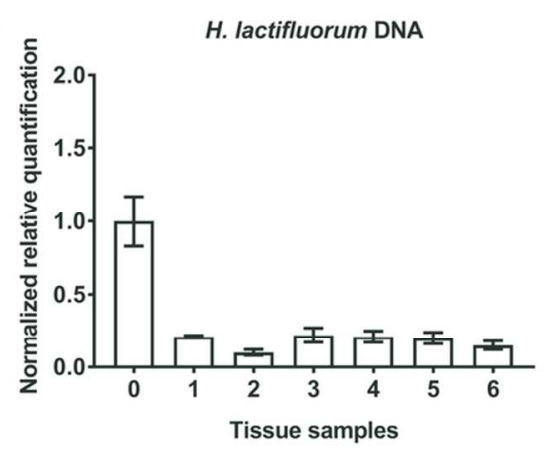

C.

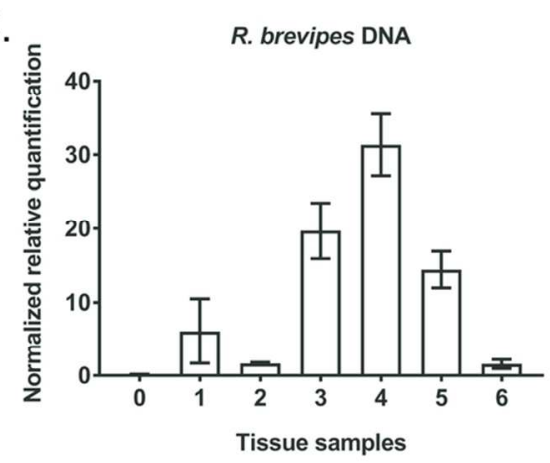

Fig. 2 qPCR results of H. lactifluorum's and R. brevipes' DNA inside sporocarp of lobster mushroom. (A) Sporocarp transversal cross-section and localization of sampled tissues. Samples 0 to 6 indicate sampled tissue localization. (B) qPCR results of H. lactifluorum's and (C) of R. brevipes' DNA inside lobster mushroom.

$46 \times 27 \mathrm{~mm}(600 \times 600 \mathrm{DPI})$ 


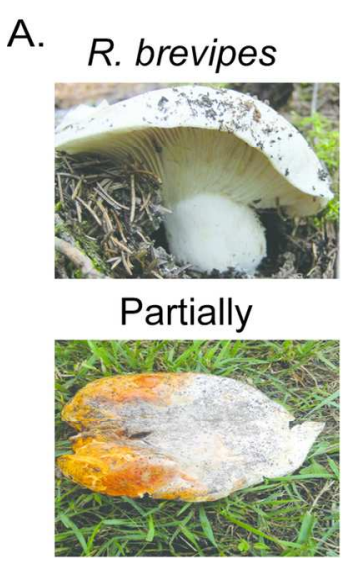

B.
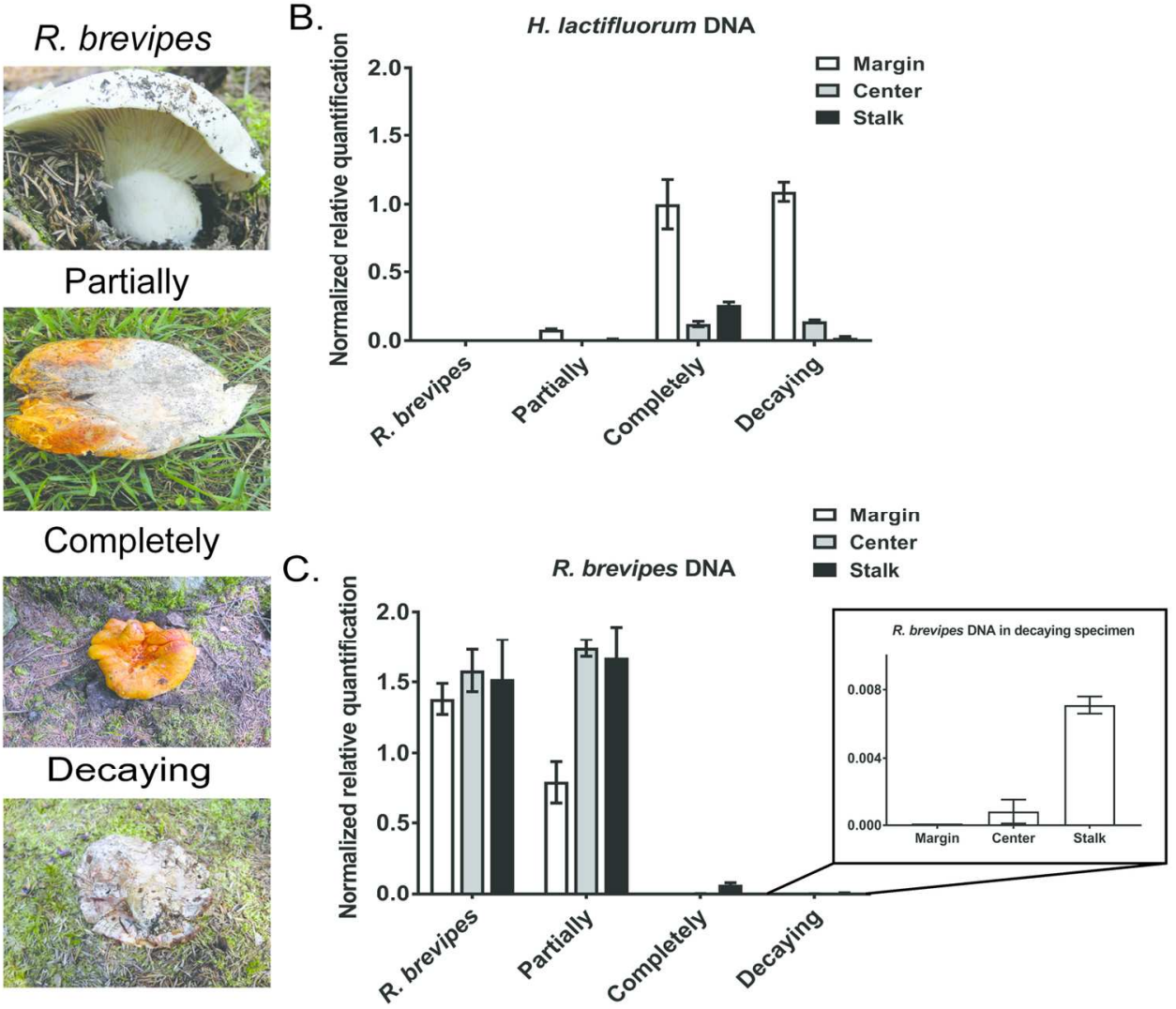

Fig. 3 qPCR results of $H$. lactifluorum's and R. brevipes' DNA at different infection stages and in R. brevipes. (A) Pictures of different infected specimens: non-infected R. brevipes, partially infected specimen, completely infected specimen (mature lobster mushroom) and decaying specimen. (B) qPCR results of $\mathrm{H}$. lactifluorum's DNA and (C) of R. brevipes' DNA in a series of samples at different infection stages.

$$
70 \times 58 \mathrm{~mm}(600 \times 600 \text { DPI })
$$


A.
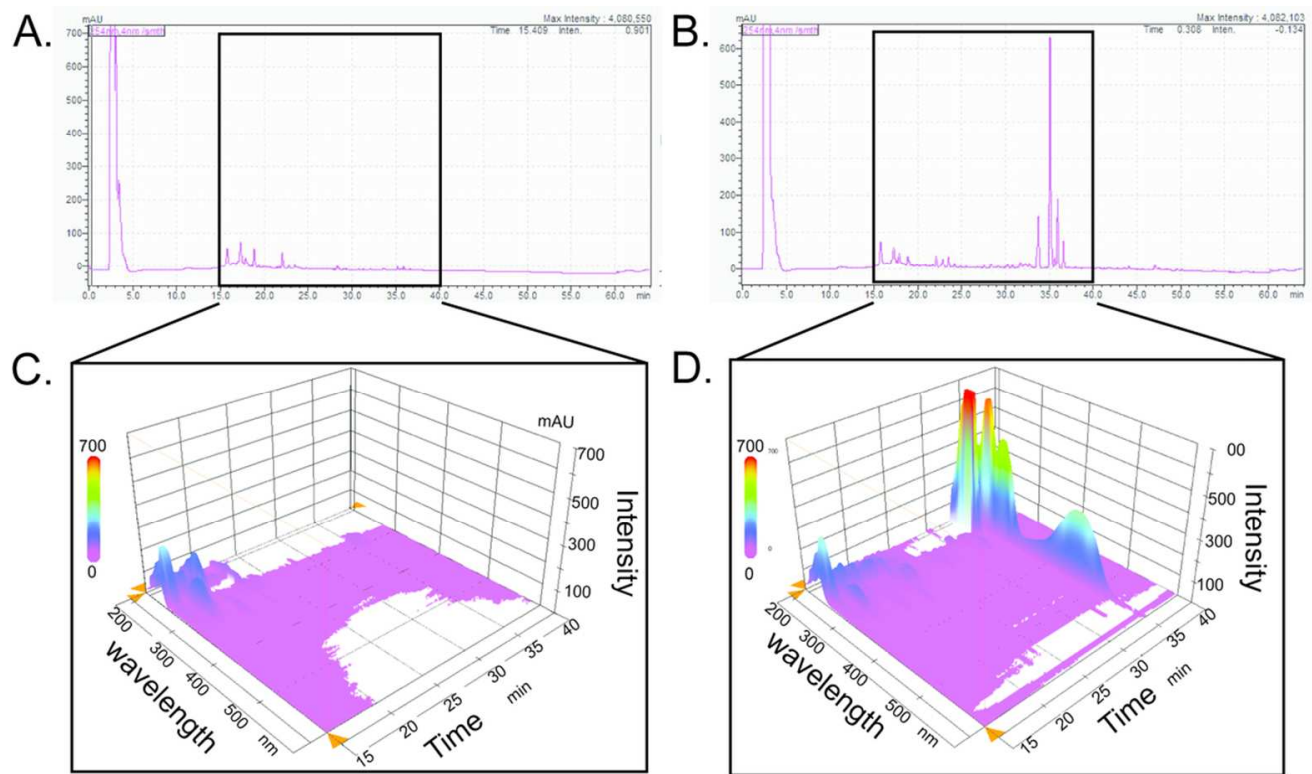

Fig. 4 HPLC chromatogram of extracts from R. brevipes and lobster mushroom specimens. (A) HPLC chromatogram at $254 \mathrm{~nm}$ of R. brevipes and (B) lobster mushroom extracts. (C) 3-D HPLC plot showing the 15-40 min range of $R$. brevipes and (D) lobster mushroom.

$49 \times 29 \mathrm{~mm}(600 \times 600 \mathrm{DPI})$ 
A.

R. brevipes

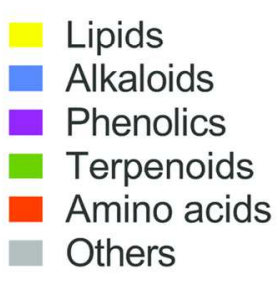

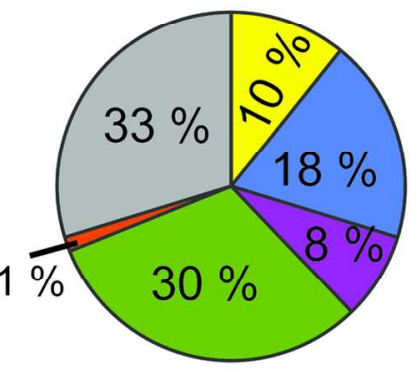

C.

R. brevipes

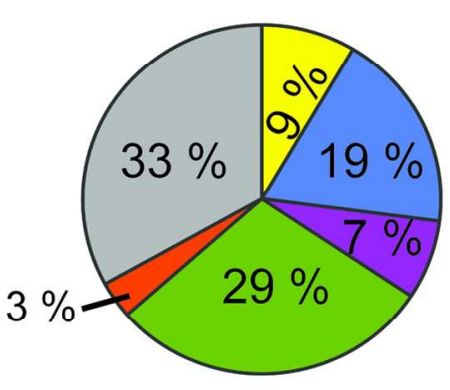

B.
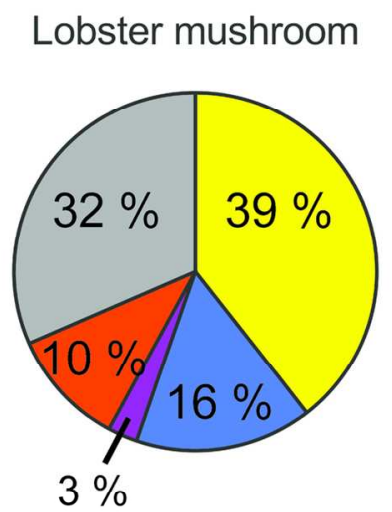

D.

Lobster mushroom

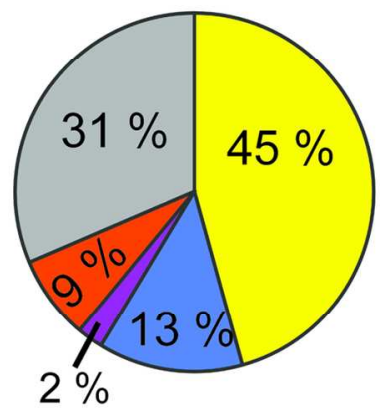

Fig. 5 Pie chart indicating some compounds groups detected by UPLC-qTOF-MS analysis. Percentage of diversity of the selected families of compounds for (A) R. brevipes and (B) lobster mushroom and the relative amount of each compound group calculated with the total area under the curve for (C) R. brevipes and (D) lobster mushroom.

$67 \times 59 \mathrm{~mm}(600 \times 600$ DPI $)$ 